\title{
The Effect of Nalidixic Acid on the Cell Cycle of Synchronous Rhodopseudomonas palustris Cultures
}

\author{
By D. WESTMACOTT* AND S. B. PRIMROSE \\ Department of Biological Sciences, University of Warwick, Coventry CV4 $7 A L$
}

(Received 29 March 1976)

\section{SUMMARY}

The influence of the DNA synthesis inhibitor, nalidixic acid, on the properties of synchronous cultures of selected Rhodopseudomonas palustris swarmer cells was examined. There was little alteration in the changes in morphology, extinction, volume distribution and leucine incorporation up to bud development, and photosynthetic membrane lamellae were still synthesized de novo in the bud. However, there was no subsequent division, or flagellum or holdfast synthesis. Instead cells elongated by continued outgrowth of the abortive bud. Since DNA synthesis was also inhibited, this suggested a dependence of cell division, and flagellum and holdfast synthesis, on the completion of chromosome replication. By addition or removal of nalidixic acid at various times in the cell cycle, periods were demonstrated when the organism was insensitive to the antibiotic indicating that there was a pre-synthetic and post-synthetic gap in the pattern of DNA synthesis in $R$. palustris swarmers.

\section{INTRODUCTION}

Nalidixic acid (NAL), an inhibitor of deoxyribonucleic acid (DNA) synthesis in both Gram-negative and Gram-positive bacteria (Goss, Deitz \& Cook, 1964, 1965; Cook et al., I966), and a number of other methods of inhibiting chromosome replication, have been used to examine the dependence of cell division on DNA replication. Donachie, Martin \& Begg (197I) used NAL as well as thymine starvation to show that cell division was not coupled to DNA replication in Bacillus subtilis, although a contradictory report on a related strain was made by Sargent (1975). In contrast, however, cell division in Escherichia coli only occurs if DNA replication has been completed (Clark, I968; Helmstetter \& Pierucci, 1968; Dix \& Helmstetter, 1973). Similarly studies on the effects of mitomycin C and hydroxyurea on DNA synthesis in Caulobacter crescentus (Degnen \& Newton, 1972a) indicated that cell division is coupled to completion of chromosome replication. Weiner \& Blackman (1973) found that NAL specifically inhibited DNA replication as well as bud formation in Hyphomicrobium neptunium, and later showed that both bud formation and separation could be inhibited by NAL during slide culture of the organism (Blackman \& Weiner, 1975), indicating that DNA replication and cell division were linked.

The photosynthetic, purple, non-sulphur bacterium Rhodopseudomonas palustris was shown by Whittenbury \& McLee (1967) to reproduce by budding motile daughter cells off the end of a tube-like extension of the parent cell. Westmacott \& Primrose (1976) have described a number of the morphological and physical changes that accompany this development in the division cycle of synchronous swarmer cell preparations. Ultrastructural

\footnotetext{
* Present address: Department of Microbiology, University of Liverpool, Liverpool L69 3BX.
} 
aspects of the cell cycle of $R$. palustris have also been investigated (Dow, Westmacott \& Whittenbury, 1976). The purpose of this investigation was to establish whether the developmental cycle of $R$. palustris was arrested or modified after inhibition of DNA synthesis, and hence what morphological stages might depend on chromosome replication. Although there has been little success in elucidating the mode of action of NAL (Boyle, Cook \& Goss, 1969; Bourguignon, Levitt \& Sternglanz, 1973) it does have the advantage over other inhibitors of DNA synthesis that its action is rapidly reversible (Ward, Hane \& Glaser, 1970). Thymine starvation could not be used as a means of inhibiting DNA synthesis as we have not been able to obtain any thymine-requiring mutants of $R$. palustris. Thus, for the purposes of this study, NAL was the preferred means of inhibiting DNA synthesis.

\section{METHODS}

Selection of synchronous populations. Cultures of $R$. palustris (isolated from fresh water by Dr C. S. Dow, Department of Biological Sciences, University of Warwick) were grown as described by Westmacott \& Primrose $\left(1975\right.$, I976) in PAYE medium at $36^{\circ} \mathrm{C}$. Selection of synchronous populations of swarmer cells by sucrose gradient centrifugation, and subsequent preparation of slide cultures, light microscopy, Coulter counter analysis and extinction measurement were all carried out as described previously (Westmacott \& Primrose, 1976).

Nalidixic acid. This was obtained from Sigma, and was prepared as a $\mathrm{I} \mathrm{mg} \mathrm{ml}^{-1}$ stock solution in $7 \mathrm{mM}$-sodium hydroxide. Stock solutions of NAL were added to PAYE to a final concentration of $50 \mu \mathrm{g} \mathrm{ml}^{-1}$. No change in the $\mathrm{pH}$ of the medium was observed.

Electron microscopy. Cells were shadowed on formvar support films with gold/palladium in an AEI MC9 vacuum coating unit. For sectioning, cells were fixed with osmium tetroxide (Ryter \& Kellenberger, 1958), stained with $0.5 \%$ (w/v) uranyl acetate, dehydrated through a series of alcohols and finally embedded in Araldite resin. Sections were cut with glass knives on a Reichert $\mathrm{OmU}_{2}$ ultramicrotome. Shadowed preparations and sections were examined on an AEI Corinth 275 electron microscope at an accelerating voltage of $60 \mathrm{kV}$ and electron micrographs were taken on Ilford N4E50 $70 \mathrm{~mm}$ line film.

Incorporation of $\left[{ }^{32} P\right]$ phosphate into DNA. Since we were unable to obtain adequate levels of incorporation of radioactive nucleotides, DNA synthesis was estimated by incorporation of [ $\left.{ }^{32} \mathrm{P}\right]$ orthophosphate (initially $84 \mathrm{Ci} \mathrm{mg}^{-1} \mathrm{P}$; The Radiochemical Centre, Amersham) into alkali-resistant, cold trichloroacetic acid (TCA)-precipitable material. Liquid cultures were labelled with $8 \mu \mathrm{Ci}\left[{ }^{32} \mathrm{P}\right]$ phosphate per ml PAYE medium, containing only I mM-phosphate buffer. At intervals, $0 . \mathrm{I} \mathrm{ml} \mathrm{samples} \mathrm{were} \mathrm{removed} \mathrm{and} \mathrm{treated} \mathrm{for} \mathrm{I} \mathrm{h}$ at $37^{\circ} \mathrm{C}$ with $\mathrm{I} \mathrm{ml}$ $0.4 \mathrm{M}$-sodium hydroxide containing Io $\mu \mathrm{g}$ bovine serum albumin $\mathrm{ml}^{-1}$. The alkali was then neutralized with I ml $0.4 \mathrm{M}$-hydrochloric acid and samples were treated with $2.5 \mathrm{ml} \mathrm{I} 8 \%$ (w/v) TCA for $30 \mathrm{~min}$ at $0^{\circ} \mathrm{C}$. The precipitated nucleic acid was washed on $2.5 \mathrm{~cm}$ Whatman GF/C filters with cold $10 \%$ (w/v) TCA, Io mM-phosphate buffer $(\mathrm{pH} 7 \cdot 0)$, ethanol and ether, and then dried. The radioactivity of the TCA-insoluble material retained on filters was estimated in Io $\mathrm{ml}$ samples of Triton X-100/toluene scintillation fluid, using a Packard Tri-Carb scintillation spectrometer.

Incorporation of $\left[{ }^{3} \mathrm{H}\right]$ leucine. Incorporation of $\left[{ }^{3} \mathrm{H}\right] l$ leucine $\left(53 \mathrm{Ci} \mathrm{mmol}^{-1}\right.$; The Radiochemical Centre) was measured in cells which had been grown overnight in PAYE supplemented with $50 \mu \mathrm{g} \mathrm{L}$-leucine $\mathrm{ml}^{-1}$. $\left[{ }^{3} \mathrm{H}\right]$ Leucine was added at an activity of $5 \mu \mathrm{Ci} \mathrm{ml}^{-1}$ to synchronous or heterogeneous subcultures of the cells in PAYE containing only $0.05 \mathrm{~g}$ yeast extract $\mathrm{l}^{-1}$, and supplemented with $\mathrm{I}$ ( $\mathrm{mg} \mathrm{L}$-leucine $\mathrm{1}^{-1}$. At intervals, $0 \cdot \mathrm{I} \mathrm{ml}$ samples 

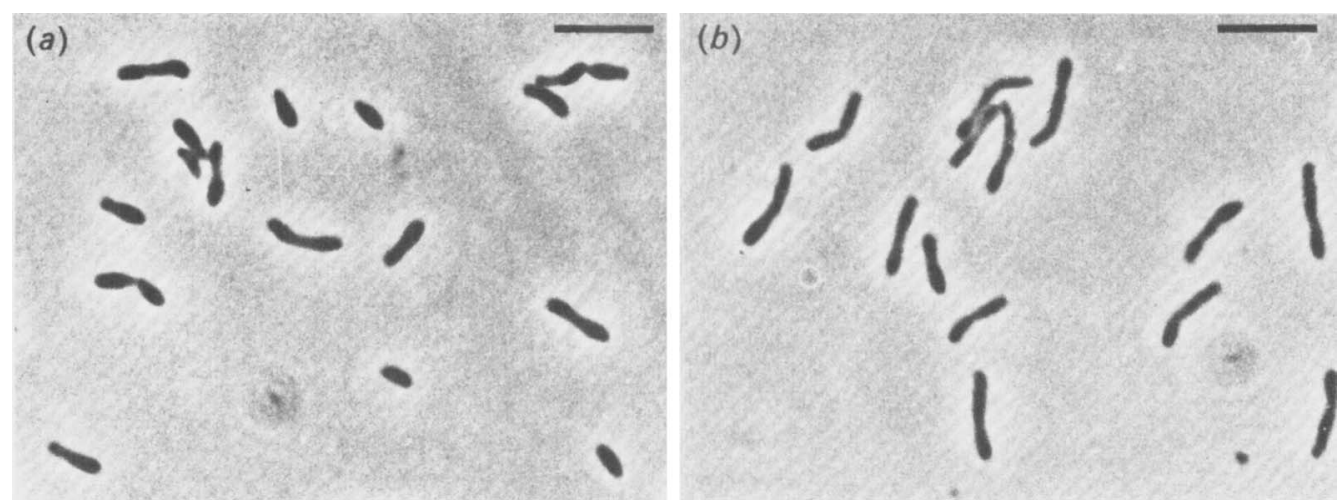

Fig. I. Phase-contrast photomicrographs of $(a)$ an untreated $R$. palustris culture and $(b)$ a culture treated for $6 \mathrm{~h}$ with NAL. Bar markers represent $5 \mu \mathrm{m}$.

were treated with $\mathrm{Iml} \mathrm{mo} \%(\mathrm{w} / \mathrm{v}) \mathrm{TCA}$ at $0^{\circ} \mathrm{C}$ for $30 \mathrm{~min}$ and then filtered, washed with a solution containing $50 \mathrm{mg}$ L-leucine $\mathrm{1}^{-1}$, dried and counted as described above.

\section{RESULTS}

\section{Morphology of treated cultures}

When heterogeneous cultures of $R$. palustris were treated with $50 \mu \mathrm{g} \mathrm{NAL} \mathrm{ml}^{-1}$, a large number of abnormally elongated cells were seen within 6 to $7 \mathrm{~h}$ of treatment (Fig. I). In order to determine the significance of these in relation to the normal division cycle of $R$. palustris, growth of a synchronous culture of isolated swarmer cells in the presence of NAL was followed by slide culture, and compared with development in a synchronous untreated control slide culture (Fig. 2). Growth in both cultures occurred at a similar rate and proceeded through the same series of morphological steps up to the stage of bud enlargement at 4 to $5 \mathrm{~h}$ (Fig. $2 d, e, l, m$ ). Subsequent growth of the untreated culture resulted in division at about $5 \mathrm{~h}$ (Fig. $2 e, f$ ) followed by renewed development of progeny. However, division was rarely observed in the NAL-treated culture. Instead, more than $90 \%$ of the cells produced a phase-contrast-opaque outgrowth beyond the abortive daughter bud. Precisely the same appearance was observed when cells were treated with mitomycin $\mathbf{C}$ at a concentration of Io $\mu \mathrm{g} \mathrm{ml}^{-1}$.

Electron microscopy of shadowed preparations of elongated cells from NAL-treated synchronous liquid cultures revealed that such cells possessed holdfasts at the non-growing mother poles (Fig. 3). However, at no time after initiation of bud development were flagella observed on the growing bud poles. This observation was supported by the fact that synchronous motile swarmer cultures in NAL, when examined by phase-contrast microscopy, were never seen to regain the motility that they had possessed during swarmer maturation.

\section{Ultrastructure}

Sections through a NAL-induced elongated cell (Fig. $4 a$ ) revealed the presence of photosynthetic membrane lamellae both in the mother portion of the cell and within the elongating bud region, but not within the tube connecting these regions. Figure $4(a)$ also shows only a relatively small area of nuclear material compared with that in untreated cells just before cell division (Fig. $4 b$ ). Generally, a considerable deformation of cell contents was observed in sections of elongated cells: photosynthetic membrane lamellae were frequently 
D. WESTMACOTT AND S. B. PRIMROSE

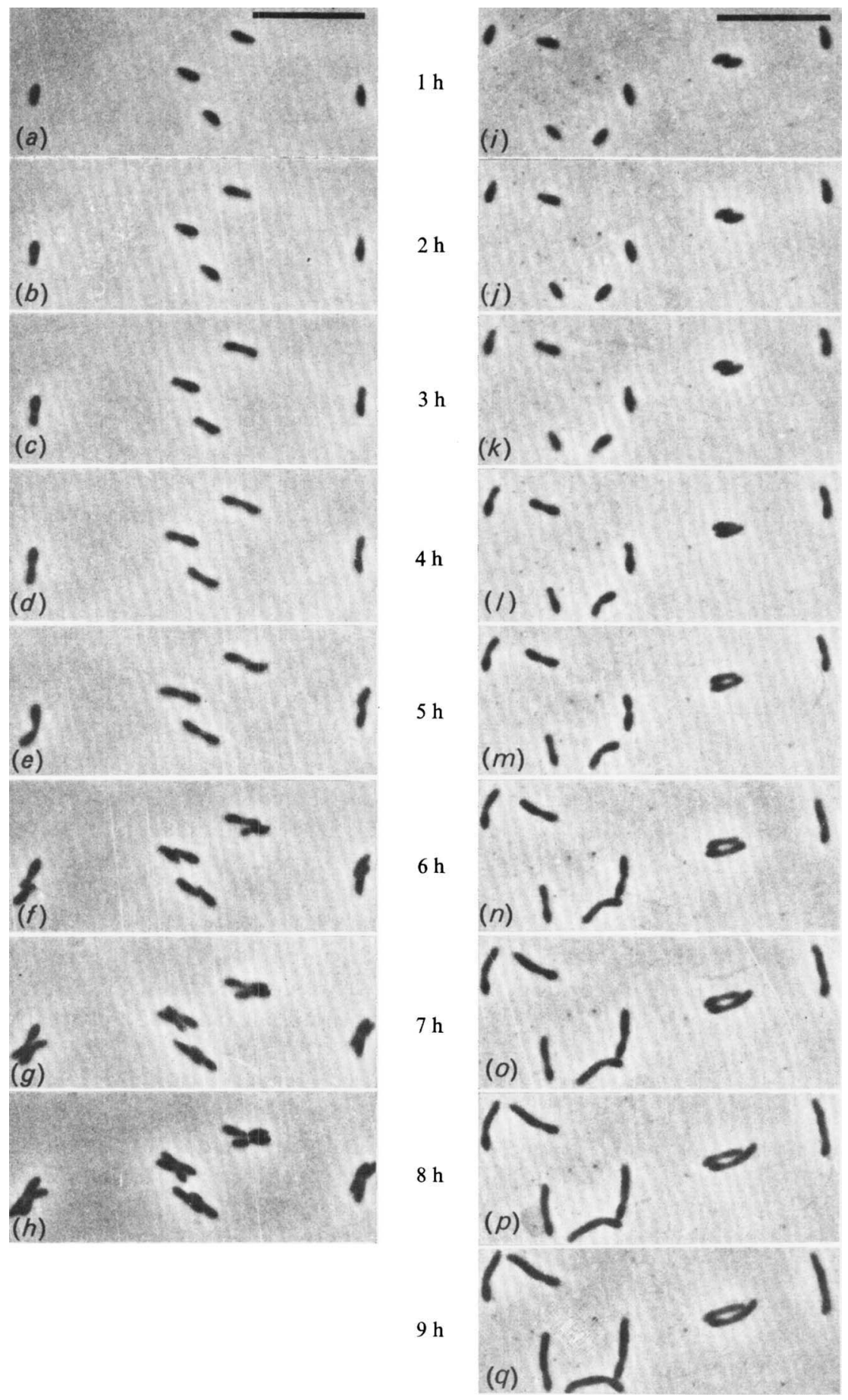

Fig. 2. Phase-contrast photomicrographs of ( $a$ to $h$ ) untreated and ( $i$ to $q$ ) NAL-treated synchronous slide cultures of $R$. palustris. Bar markers represent 10 $\mu \mathrm{m}$. 

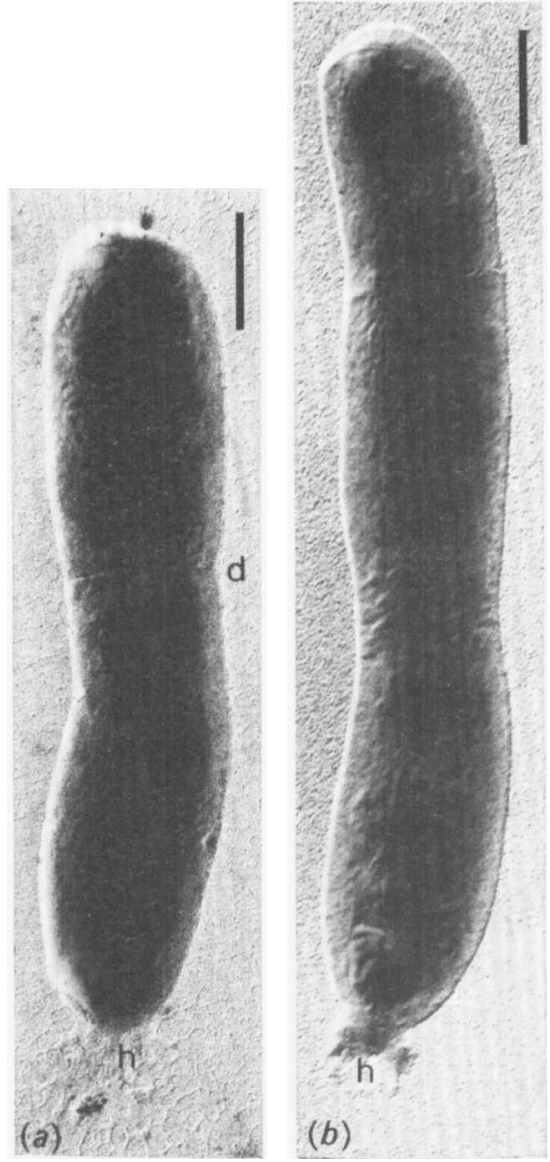

Fig. 3
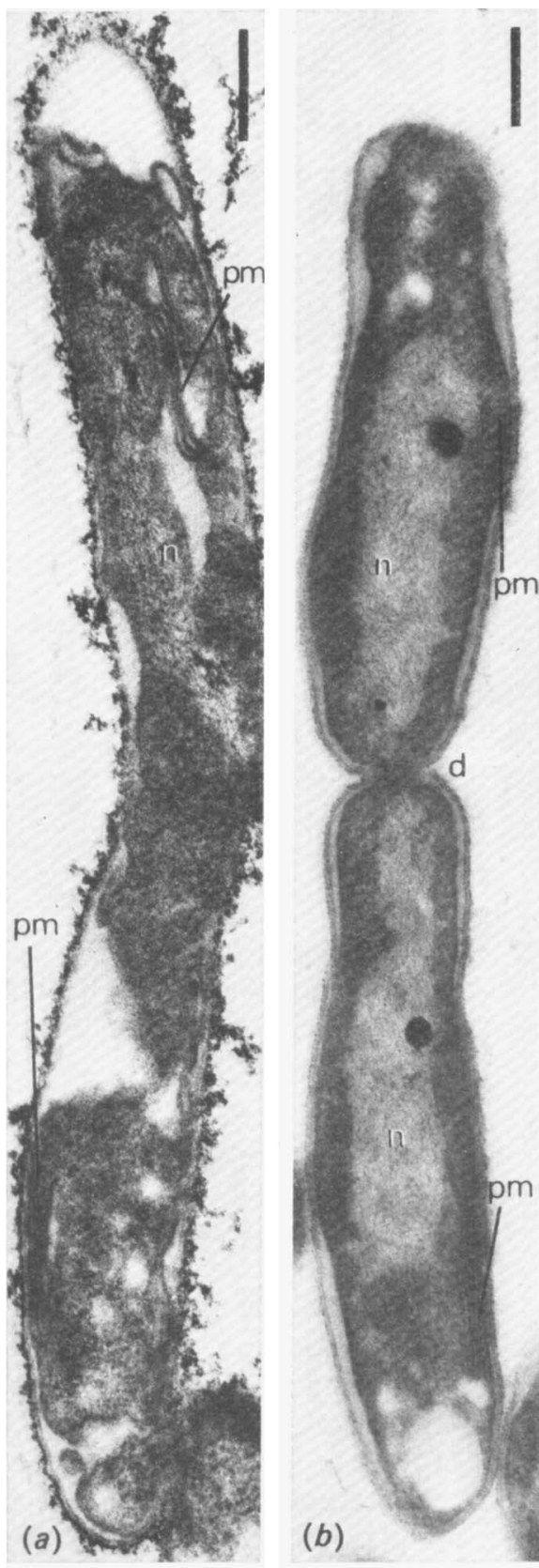

Fig. 4

Fig. 3. Gold/palladium shadowed $R$. palustris cells: $(a)$ untreated cell with mature bud; $(b)$ elongated cell from a culture treated with NAL for $6 \mathrm{~h} . \mathrm{h}$, Holdfast; d, division plane. Bar markers represent $0.5 \mu \mathrm{m}$.

Fig. 4. Longitudinal sections of $(a)$ NAL-treated and $(b)$ untreated dividing $R$. palustris cells. pm, Photosynthetic membrane lamellae; $n$, nuclear material; $d$, division constriction. Bar markers represent $0.2 \mu \mathrm{m}$. 


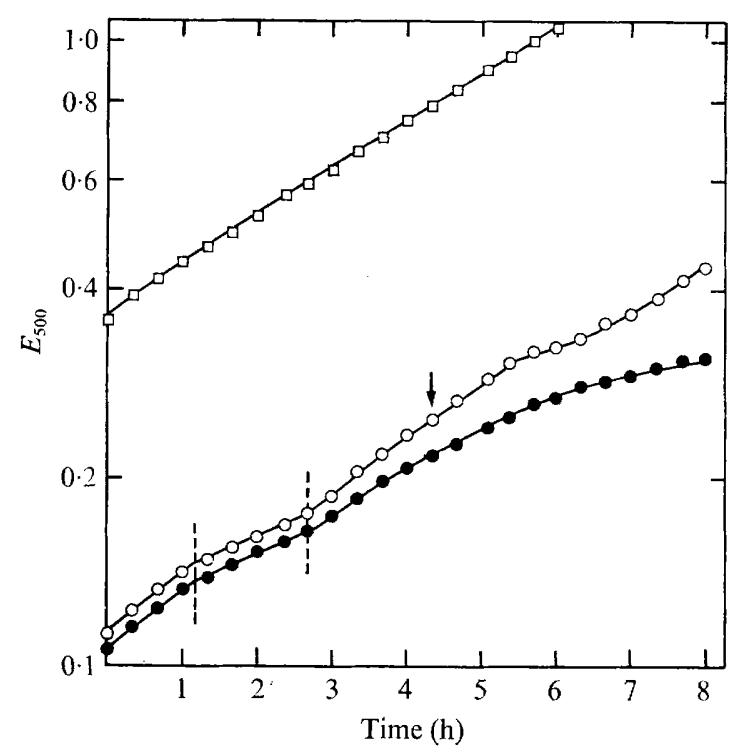

Fig. 5. Effect of NAL on extinction changes of synchronous culture of $R$. palustris. Changes of $E_{500}$ were followed in untreated $(O)$ and NAL-treated $(\bullet)$ synchronous cuvette cultures and compared with that in an untreated heterogeneous control culture $(\square)$. The approximate time of division in the untreated synchronous culture is indicated by the arrow.

distorted and convoluted and apparent vacuoles were often observed, particularly at the elongated growing pole. Polar collections of these vacuoles were sometimes also seen by light microscopy after treatment with NAL for long periods. There was no evidence in sections for the presence of two nuclear bodies in elongated cells.

\section{Extinction changes}

Changes in $E_{500}$ of untreated and NAL-treated synchronous cuvette cultures were compared during $8 \mathrm{~h}$ incubation (Fig. 5). Although there was an exponential increase in the extinction of a heterogeneous control, the untreated synchronous culture showed three rates of increase in the first generation, as described previously (Westmacott \& Primrose, 1976). The first two phases, lasting $\mathrm{I} \cdot 2$ and $\mathrm{I} \cdot 5 \mathrm{~h}$, and corresponding to swarmer maturation and tube elongation, were also seen in the NAL-treated culture. However, the rate of extinction increase after initiation of bud formation was lower in the NAL-treated culture than in the synchronous control, particularly after about $6 \mathrm{~h}$. Thus, again, development proceeded normally at the beginning of the cycle but differences appeared during bud development, although the increase in extinction was not completely inhibited during $8 \mathrm{~h}$ incubation. Division was observed in the untreated synchronous culture at 4 to $4.5 \mathrm{~h}$ and consequently the duration of the experiment represented nearly two swarmer cell cycles.

\section{Coulter counter analysis}

The effect of NAL on the increase in volume of synchronous $R$. palustris cultures was examined using the Coulter counter and Channelyzer. Volume distributions of NAL-treated synchronous cultures obtained between $o$ and $7 \mathrm{~h}$ growth are shown in Fig. 6. As in untreated swarmer cultures (Westmacott \& Primrose, 1976), selected swarmers presented a very narrow distribution of volumes, initially having a peak at about $0.26 \mu \mathrm{m}^{3}$ and gradually 


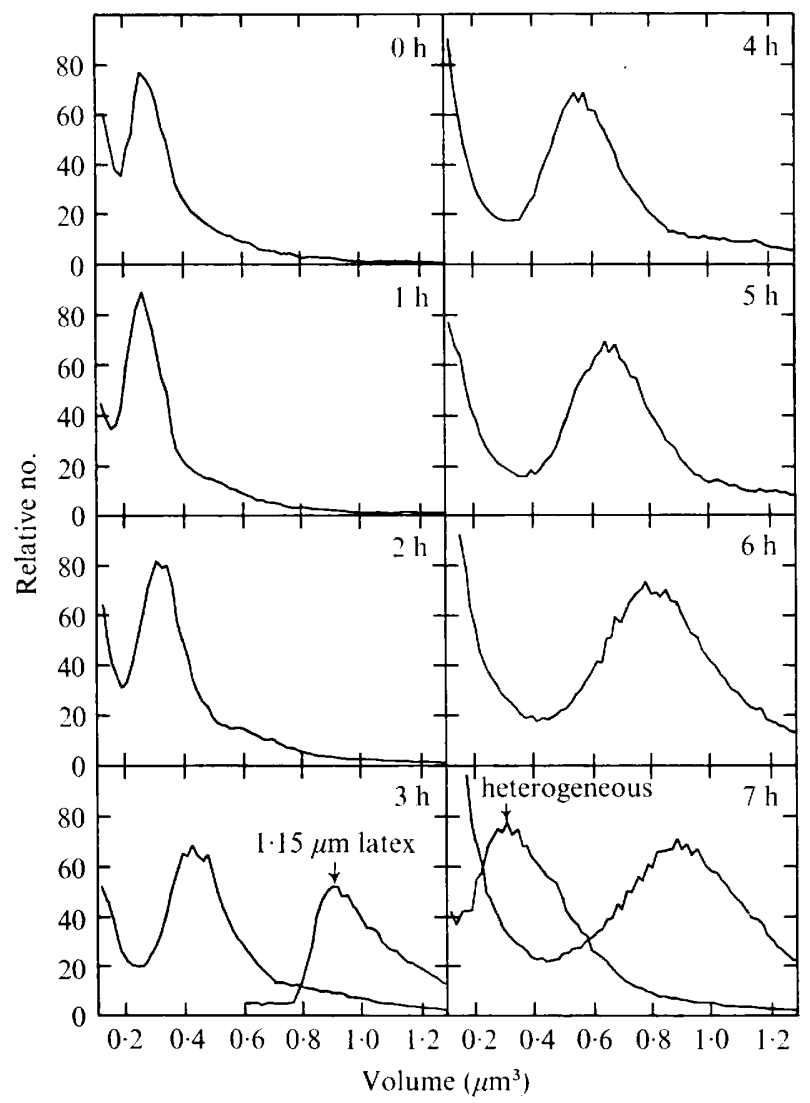

Fig. 6. Volume distribution of a NAL-treated synchronous culture of $R$. palustris. Samples were taken at intervals during the synchronous development in the presence of NAL and the volume distribution of suspended particles was analysed using a Coulter counter and Channelyzer.

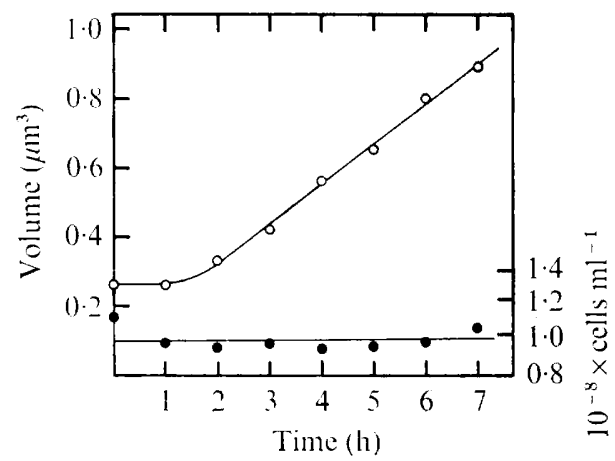

Fig. 7. Peak volume changes and total particle counts in a synchronous culture of $R$. palustris in the presence of NAL. The most frequent volumes observed in the distributions shown in Fig. $6(O)$ were plotted against time, and compared with particle counts (O) obtained on analysis of the same samples with the Coulter counter. 


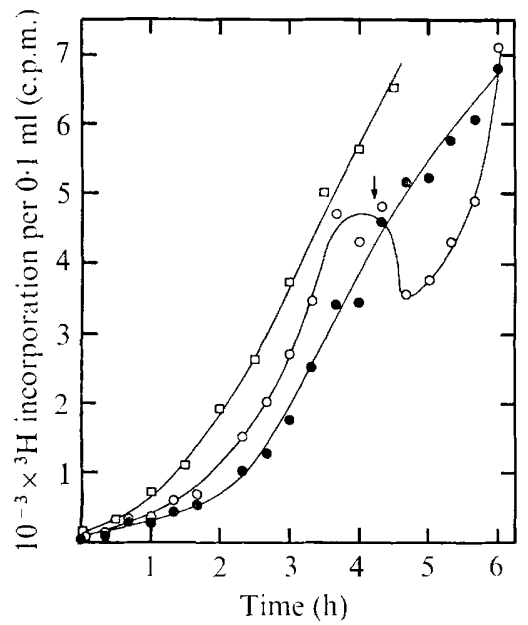

Fig. 8

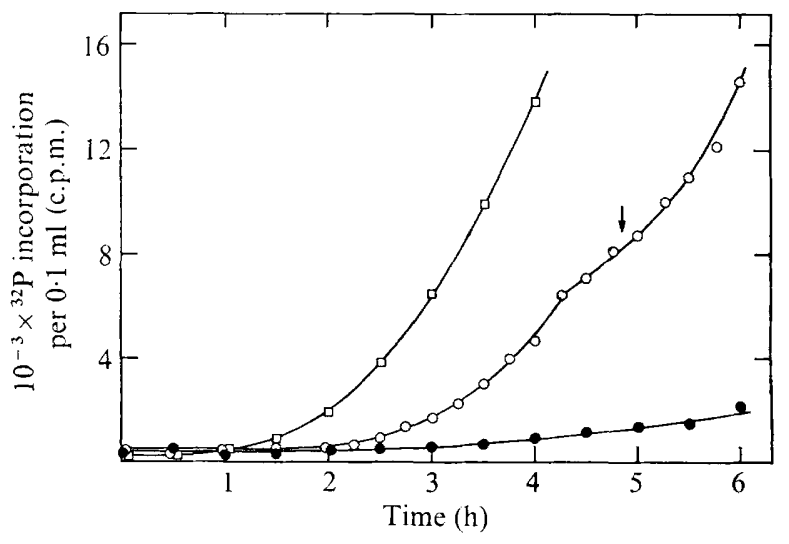

Fig. 9

Fig. 8. Effect of NAL on incorporation of $\left[{ }^{3} \mathrm{H}\right]$ leucine by synchronous $R$. palustris cultures. Incorporation by untreated synchronous $(O)$ and NAL-treated synchronous $(O)$ cultures was compared with that by an untreated heterogeneous control culture ( $\square$ ). The approximate time of division in the untreated synchronous culture is indicated by the arrow.

Fig. 9. Effect of NAL on incorporation of [ $\left.{ }^{32} \mathrm{P}\right]$ phosphate into alkali-resistant fractions (largely DNA) of $R$. palustris synchronous cultures. Incorporation by untreated synchronous ( $O$ ) and NALtreated synchronous $(\boldsymbol{O})$ cultures was compared with that by an untreated heterogeneous control culture $(\square)$. The approximate time of division in the untreated synchronous culture is indicated by the arrow.

increasing in peak volume during incubation. However, instead of forming a double peak characteristic of division, the volumes continued to increase to the end of the experiment. After $7 \mathrm{~h}$ incubation the peak was broader (higher standard deviation), but it indicated a mean volume of $0.89 \mu \mathrm{m}^{3}: 3.4$ times the volume of the original swarmers. This final volume represented a $40 \%$ increase in the maximum peak volume attained in $7 \mathrm{~h}$ by untreated synchronous cultures (Westmacott \& Primrose, 1976).

When the peak volumes shown in Fig. 6 were plotted against time (Fig. 7), an initial lag in volume increase was seen, just as in untreated synchronous cultures, but was followed by a continuous linear volume increase. No drop in volume increase was observed over the $7 \mathrm{~h}$ in NAL-treated synchronous cultures. In addition total particle counts made on dilutions of culture samples (Fig. 7) indicated no increase in the number of cells at the expected time for division and little change elsewhere. Thus it was confirmed by Coulter counter analysis that NAL inhibited division in synchronous cultures of $R$. palustris, but not volume increase; and hence growth of the cells, both before and after the normal time of division, was unaffected.

\section{Incorporation of $\left[{ }^{3} \mathrm{H}\right]$ leucine}

When incorporation of $\left[{ }^{3} \mathrm{H}\right]$ leucine by an untreated synchronous culture was compared with that of a heterogeneous control (Fig. 8) it was found that there was a sharp drop in radioactivity at about the time of division of the synchronous culture. Thus it seems that at division there was a loss of radioactive material from the cells into the culture medium. Incoporation in the second generation continued at a considerably higher rate than at the beginning of the first, presumably as a result of there being twice as many cells. When incorporation by a synchronous culture treated with NAL was compared with the untreated 


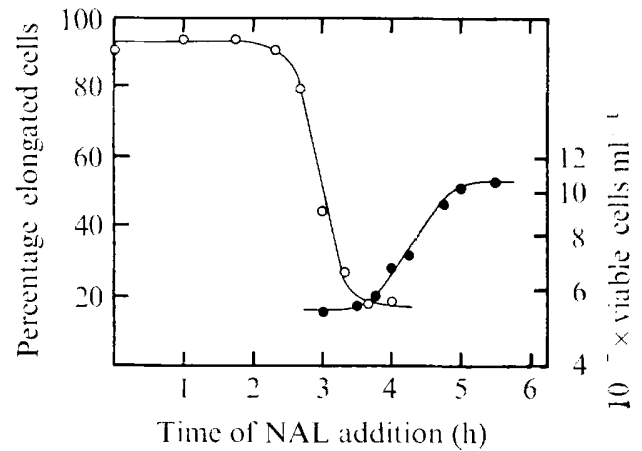

Fig. Io

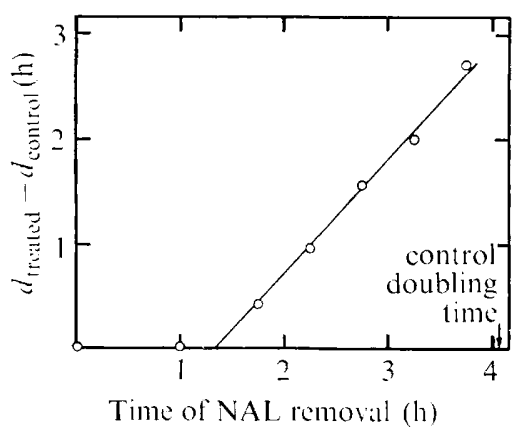

Fig. II

Fig. IO. Effect of NAL treatment commenced at intervals in the division cycle of $R$. palustris. The proportion of elongated cells present in synchronous cultures after $6 \mathrm{~h}$ was determined and corrected for the estimated increase in cell numbers due to division of unaffected cells $(\bigcirc)$. Numbers of viable cells in a parallel untreated synchronous culture were determined by the spread plate method (O).

Fig. I I. Delay in doubling time observed in NAL-treated synchronous $R$. palustris cultures where NAL was effectively removed by dilution at intervals in the division cycle. The doubling time of a culture diluted at o $\mathrm{h}$ was considered as the untreated control $\left(d_{\text {control }}\right)$ and was subtracted from doubling times obtained for other times of dilution to remove NAL $\left(d_{\text {treated }}\right)$. See Table I for doubling times.

culture the pattern of uptake was very similar up to $3.75 \mathrm{~h}$, but no drop in radioactivity occurred. Instead there was a gradual continuation of $\left[{ }^{3} \mathrm{H}\right]$ leucine incorporation. Clearly, NAL did not have any inhibitory effect on protein synthesis that could be detected by this means. Furthermore, the inhibition of division allowed continuous gross incorporation of $\left[{ }^{3} \mathrm{H}\right]$ leucine to occur, indicating that the drop in radioactivity in the untreated culture is linked to the process of division.

\section{Incorporation of $\left[{ }^{32} P\right]$ phosphate into DNA}

The incorporation of [ $\left.{ }^{32} \mathrm{P}\right]$ phosphate into alkali-resistant fractions (DNA) by untreated and NAL-treated synchronous cultures is shown in Fig. 9. There was a rapid increase in ${ }^{32} \mathrm{P}$ uptake in the untreated synchronous control after about $2 \mathrm{~h}$; that is, approximately $2.7 \mathrm{~h}$ before division. The lag in DNA synthesis did not seem to be due to physiological or nutritional shock during synchronization since a heterogeneous culture, obtained by mixing all cell layers from a sucrose gradient, incorporated ${ }^{32} \mathrm{P}$ into DNA at a gradually increasing rate from $o \mathrm{~h}$. However, when incorporation was followed in the NAL-treated synchronous culture, the results indicated that there was little DNA synthesis during $6 \mathrm{~h}$ incubation.

\section{Treatment with NAL at different developmental stages}

Parallel synchronous cultures of $R$. palustris were treated at different stages of development with NAL and allowed to continue to grow until division would normally have been complete $(6 \mathrm{~h})$. The proportions of elongated cells were then estimated, numbers being corrected to allow for those cells which did duplicate and thus to relate to the proportions of first generation cells affected by NAL (Fig. I0). The effect of NAL at different times of treatment was compared with the increase in viable cell numbers obtained from a further parallel synchronous culture prepared from the same stock of selected swarmer cells. Treatment of the cells during the first $2.5 \mathrm{~h}$ of the cell cycle resulted in at least $90 \%$ of the cells becoming elongated. By $3 \mathrm{~h}$ only half of the population produced elongated cells, and 
Table I. Effect of terminating NAL-treatment at intervals in the cell cycle of $R$. palustris on the timing of division

Seven parallel synchronous cultures were treated at zero time with $50 \mu \mathrm{g} \mathrm{NAL} \mathrm{ml} l^{-1}$ and at various times in the cell cycle diluted $\mathrm{IO}^{-\mathbf{s}}$ to terminate the antibiotic action. Mean doubling times were estimated from subsequent viable plate counts.

$\begin{array}{cc}\begin{array}{c}\text { Time of } \\ \text { NAL removal (h) }\end{array} & \begin{array}{c}\text { Mean } \\ \text { doubling time (h) }\end{array} \\ 0 & 4.07 \\ \text { I } & 4.10 \\ 1.75 & 4.50 \\ 2.25 & 5.03 \\ 2.75 & 5.63 \\ 3.25 & 6.07 \\ 3.75 & 6.78\end{array}$

microscopic examination of the cultures at this time showed that the cells were midway through bud formation. After $3.5 \mathrm{~h}$ incubation, more than $80 \%$ of the cells were unaffected by NAL and went on to divide normally. There was no indication of cells exhibiting late or abnormal division. Plate counts showed that division occurred with a mean doubling time of $4.3 \mathrm{~h}$. This experiment demonstrated that there was a long period (about $\mathrm{I} \cdot 3 \mathrm{~h}$ ) before division when division of the synchronous population was not inhibited by NAL. Since NAL has already been shown to inhibit specifically DNA replication these results suggest that division in $R$. palustris is closely linked to DNA synthesis and that at $2.9 \mathrm{~h}$ the particular event or time during DNA replication (probably termination) that is involved in the triggering of division has been passed.

\section{Removal of NAL at different developmental stages}

A synchronous culture was treated with NAL at zero time and samples were taken at the various stages of the subsequent development. These samples were immediately diluted and transferred to pre-warmed PAYE medium in sealed tubes gassed with oxygen-free nitrogen, thus allowing continued development of the sample cells in the effective absence of NAL. Plate counts were carried out on these NAL-free subcultures and mean doubling times were estimated (Table I). The viable counts obtained indicated that the longer periods of NAL treatment had no greater killing effect on the cells. Although removal of NAL after I h had no effect on the doubling time, removal at times later in the cell cycle gave rise to progressively longer doubling times. By plotting the difference between the mean doubling times of treated samples and the effectively untreated control against the time of dilution to remove the NAL (Fig. II), it was demonstrated that there was no delay in cell division when synchronous cells were treated with NAL for up to $\mathrm{I} \cdot 3 \mathrm{~h}$. This was $2.8 \mathrm{~h}$ before division occurred in the control culture and corresponded approximately to the beginning of tube elongation. The subsequent delay in division was directly proportional and almost equal to the time after $\mathrm{I} \cdot 3 \mathrm{~h}$ when the NAL was diluted from the culture. Clearly NAL had no inhibitory effect on division during the first $\mathrm{I} \cdot 3 \mathrm{~h}$ of the cell cycle.

\section{DISCUSSION}

The treatment of synchronous swarmer populations of $R$. palustris with NAL had three profound effects: replication of DNA was inhibited; cell division was inhibited; and continued polar growth occurred beyond the normal maximum length of the cells. Since identical results could be obtained with NAL or mitomycin $\mathrm{C}$ the primary cause of these 
observations was likely to be the inhibition of DNA replication. Although some doubt has recently been cast on the specificity of NAL action (Javor, I974; Shuman \& Schwartz, I975) it is clear from our results that, apart from chromosome replication, the developmental events at least up to bud maturation proceeded normally. Morphology, extinction changes and particle volume distributions, were as previously described for untreated cultures (Westmacott \& Primrose, I976) and only showed alterations just before and subsequent to the normal time of division. The pattern of $\left[{ }^{3} \mathrm{H}\right]$ leucine incorporation exhibited by developing $R$. palustris swarmers indicated that protein synthesis was generally unaffected by NAL, except that the curious incorporation pattern relating to division was not observed. This decrease in the level of incorporation, which seemed to result directly from division, might have been caused by leakage or excretion of protein during division. Alternatively, protein turnover might have increased dramatically, rendering the otherwise insoluble incorporated material soluble in cold TCA. The significance of these observations is not known, but it is possible that such losses may be concerned with very rapid synthesis and excretion of flagellin.

The ultrastructure of elongated cells indicated that intracellular development compared closely with that normally observed (Dow et al., 1976) with the exception that there was little or no increase in the size of nuclear bodies. Since photosynthetic membranes were observed in buds of $R$. palustris developing in the presence of NAL it seems that their synthesis de novo in a specific location is not triggered or controlled by the daughter genome whilst it is being synthesized. Instead, they must result from transcription of the mother cell genome at a specific time. Westmacott \& Primrose (1976) suggested the need for differential control of the mother and daughter genomes of $R$. palustris, but this observation illustrates the complexity of the control system. Although photosynthetic membrane synthesis and wall extension were apparently independent of chromosome replication, division and synthesis of flagella and holdfasts on the developing bud cells were apparently inhibited by NAL. This suggests a common control of these three phenomena; transcription of the appropriate genes either occurs at early stages of the swarmer maturation sequence or is linked to the completion of some stage of chromosome replication.

An examination of the incorporation of $\left.{ }^{32} \mathrm{P}\right]$ phosphate into alkali-resistant fractions demonstrated that DNA synthesis was almost completely inhibited by NAL. Although there appeared to be a lag before the normal onset of DNA synthesis, the method was probably insufficiently specific to establish the precise kinetics of genome replication. In addition, the use of reduced levels of phosphate may have influenced the results as pool concentrations became altered. However, by addition or removal of NAL from synchronous cultures of $R$. palustris it was possible to pinpoint the times of completion (onset of insensitivity of division to NAL) and initiation of chromosome replication, respectively. Just as in the well documented chromosome replication cycle of E. coli (Helmstetter \& Pierucci, I968; Clark, 1968; Dix \& Helmstetter, 1973; Burdett \& Murray, 1974), there was a D period before division during which inhibition of DNA synthesis had no effect on subsequent division. This suggests a controlling link between the two events. A lag before DNA synthesis like that demonstrated here for $R$. palustris swarmer cell cycles has also been shown in Caulobacter crescentus (Degnen \& Newton, I972b). Indeed, the cell cycles of $R$. palustris and $C$. crescentus are superficially very similar: division in both cases gives rise to a motile swarmer and an appendaged cell. If DNA replication patterns in the two organisms are truly similar, the initial lag in $R$. palustris swarmer DNA replication would not be expected in the development of mother cells in the second generation. As in Caulobacter, this raises the problem of how initiation of chromosome replication might be controlled to occur at different times for the two progeny cells. Non-diffusible or structural 
requirements, as proposed for Caulobacter by Degnen \& Newton (1972b), which are only satisfied after a period of development such as swarmer maturation would seem a possible controlling mechanism for $R$. palustris.

We are indebted to Professor R. Whittenbury and Dr C. S. Dow for providing a firm foundation of techniques and ideas on which much of this work was based. In particular, the latter gave much expert guidance during electron microscopy studies. During the course of part of this work the Coulter counter and Channelyzer were kindly loaned by Coulter Electronics Ltd. D. W. was in receipt of a studentship from the Medical Research Council.

\section{REFERENCES}

Blackman, M. A. \& WeIner, R. M. (I975). Photomicrography of nalidixic acid treated Hyphomicrobium neptunium: inhibition of bud formation and bud separation. Canadian Journal of Microbiology 21, 226-230.

Bourguignon, G. J., Levitt, M. \& Sternglanz, R. (1973). Studies on the mechanism of action of nalidixic acid. Antimicrobial Agents and Chemotherapy 4, 479-486.

Boyle, J. V., CooK, T. M. \& Goss, W. A. (1969). Mechanism of action of nalidixic acid on Escherichia coli. VI. Cell-free studies. Journal of Bacteriology 97, 230-236.

BurdetT, I. D. J. \& MurRay, R. G. E. (I974). Electron microscopy study of septum formation in Escherichia coli strains B and B/r during synchronous growth. Journal of Bacteriology Ir9, I039-1056.

ClARK, D. J. (I968). Regulation of deoxyribonucleic acid replication and cell division in Escherichia coli B/r. Journal of Bacteriology 96, I214-1224.

Cook, T. M., Brown, K. G., Boyle, J. V. \& Goss, W. A. (I966). Bactericidal action of nalidixic acid on Bacillus subtilis. Journal of Bacteriology 92, 1510-1514.

Degnen, S. T. \& Newton, A. (I972a). Dependence of cell division on the completion of chromosome replication in Caulobacter crescentus. Journal of Bacteriology Iro, 852-856.

Degnen, S. T. \& Newton, A. (1972 b). Chromosome replication during development in Caulobacter crescentus. Journal of Molecular Biology 64, 67I-680.

Dix, D. E. \& HelmsteTter, C. E. (I973). Coupling between chromosome replication and cell division in Escherichia coli. Journal of Bacteriology $115,786-795$.

Donachie, W. D., Martin, D. T. M. \& BeGG, K. J. (I97I). Independence of cell division and chromosome replication in Bacillus subtilis. Nature, New Biology 231, 274-276.

Dow, C. S., WestmacotT, D. \& WhitTenbuRY, R. (1976). Ultrastructure of budding and prosthecate bacteria. In Microbial Ultrastructure. The Use of the Electron Microscope, Society of Applied Bacteriology Technical Series ro, pp. 187-220. Edited by R. Fuller and D. W. Lovelock. London: Academic Press.

Goss, W. A., Deitz, W. H. \& Cook, T. M. (1964). Mechanism of action of nalidixic acid on Escherichia coli. Journal of Bacteriology 88, I I I 2-I I 18.

Goss, W. A., DeITz, W. H. \& Cook, T. M. (1965). Mechanism of action of nalidixic acid on Escherichia coli. II. Inhibition of deoxyribonucleic acid synthesis. Journal of Bacteriology 89, 1068-1074.

Helmstetter, C. E. \& Pierucci, O. (I968). Cell division during inhibition of deoxyribonucleic acid synthesis in Escherichia coli. Journal of Bacteriology 95, I627-1633.

JAVOR, G. T. (1974). Inhibition of ribonucleic acid synthesis by nalidixic acid in Escherichia coli. Journal of Bacteriology 120, 282-286.

Ryter, A. \& Kellenberger, E. (1958). Étude au microscope électronique de plasmas contenant de l'acide désoxyribonucléique. I. Les nucléoides des bactéries en croissance active. Zeitschrift für Naturforschung I3b, 597-605.

SARGENT, M. G. (1975). Control of cell length in Bacillus subtilis. Journal of Bacteriology 123, 7-19.

Shuman, H. \& Schwartz, M. (1975). The effect of nalidixic acid on the expression of some genes in Escherichia coli $\mathrm{K}-\mathrm{I}$ 2. Biochemical and Biophysical Research Communications 64, 204-209.

WARD, C. B., HANe, M. W. \& Glaser, D. A. (1970). Synchronous reinitiation of chromosome replication in $E$. coli $\mathrm{B} / \mathrm{r}$ after nalidixic acid treatment. Proceedings of the National Academy of Sciences of the United States of America 66, 365-369.

WeINER, R. M. \& BLACKMAN, M. A. (I973). Inhibition of deoxyribonucleic acid synthesis and bud formation by nalidixic acid in Hyphomicrobium neptunium. Journal of Bacteriology 116, 1398-1404.

WestmacotT, D. \& Primrose, S. B. (1975). An anaerobic bag for photoheterotrophic growth of some Rhodospirillaceae in Petri dishes. Journal of Applied Bacteriology 38, 205-207.

WestmacotT, D. \& Primrose, S. B. (1976). Synchronous growth of Rhodopseudomonas palustris from the swarmer phase. Journal of General Microbiology 94, I I 7-r 25.

Whittenbury, R. \& MCLee, A. G., (I967). Rhodopseudomonas palustris and Rh. viridis-photosynthetic budding bacteria. Archiv für Mikrobiologie 59, 324-334. 